\title{
GAS EXCHANGE AND CARBOHYDRATE PARTITIONING IN COFFEE SEEDLINGS UNDER WATERLOGGING
}

\author{
Trocas gasosas e particionamento de carboidratos em \\ mudas de café sob encharcamento
}

\author{
Helbert Rezende de Oliveira Silveira ${ }^{1}$, Kamila Rezende Dázio de Souza ${ }^{2}$, Jose Donizeti Alves ${ }^{3}$, \\ Meline de Oliveira Santos ${ }^{3}$, Cínthia Aparecida Andrade ${ }^{3}$, Sandro Costa Bomfim ${ }^{4}$
}

\begin{abstract}
Irrigation has enhanced coffee production in several regions of Brazil. However, with the increase in irrigated crop areas, problems related to the frequent and poorly planned usage of irrigation may arise. Since there are few studies related to the physiological alterations in coffee plants exposed to water excess, we evaluated the effects of waterlogging on metabolism and partitioning of carbohydrates, levels of photosynthetic pigments and gas exchange in seedlings of two commercial coffee cultivars (Mundo Novo and Catuaí). After acclimation, seedlings with eight pairs of fully expanded leaves were cultivated under three water availability conditions: field capacity, intermittent waterlogging and continuous waterlogging. Gas exchange and the levels of chlorophyll, carotenoids and carbohydrates were evaluated during the five months after the beginning of the treatments. Waterlogging reduced the rates of photosynthesis and transpiration, leading to lower activity of the carboxylative step of photosynthesis and culminating in the reduction of carbohydrate partitioning in coffee seedlings. Although many physiological parameters were affected by waterlogging, the cultivars in our study survived for five months under stressful conditions.
\end{abstract}

Index terms: Water excess; photosynthesis; reducing sugars; stomatal conductance; water efficiency use.

\section{RESUMO}

A irrigação tem aumentado a produção de café em muitas regiões do Brasil. Entretanto, com o aumento das áreas de produção irrigadas, problemas relacionados à irrigação frequente e mal planejada podem surgir. Em decorrência de poucos estudos ligados às alterações fisiológicas em plantas de cafeeiro submetidas ao excesso de água, avaliaram-se os efeitos do encharcamento no metabolismo e no particionamento de carboidratos, níveis de pigmentos fotossintéticos e trocas gasosas em mudas de duas cultivares comerciais de café (Mundo Novo e Catuaí). Após aclimatação, as mudas, contendo oito pares de folhas completamente expandidas, foram cultivadas em três condições de disponibilidade de água: capacidade de campo, encharcamento intermitente e encharcamento contínuo. As trocas gasosas e os níveis de clorofilas, carotenóides e carboidratos foram avaliados por cinco meses, após o início dos tratamentos. O encharcamento reduziu as taxas de fotossíntese e transpiração, levando a uma menor atividade da etapa carboxilativa da fotossíntese, culminando com a redução do particionamento de carboidratos nas mudas de café. Apesar de os parâmetros analisados terem sido afetados pelo encharcamento, as cultivares deste estudo sobreviveram por cinco meses sob essas condições de estresse.

Termos para indexação: Excesso hídrico; fotossíntese; açúcares redutores; condutância estomática; eficiência do uso da água.

\section{INTRODUCTION}

Irrigation allows the production of high quality coffee (Coffea arabica L.) in areas previously considered marginal for its cultivation due to extended periods of water deficiency (Lemos Filho et al., 2010). Moreover, the decreasing cost of irrigation systems has led to the adoption of this approach in traditional coffee-cultivation regions with the aim of producing higher yields (Rotondano et al., 2005).
Despite the benefits for coffee cultivation, poorly planned irrigation can lead to excessive water in the soil, compromising seedling development and even reducing the yield of coffee trees. Water excess affects the growth of coffee seedlings, leading to premature leaf fall and reduced numbers of absorbent roots (Silveira et al., 2014). Furthermore, excessive irrigation during the reproductive stage leads to the desynchronization of flowering, affecting the uniformity of fruit maturation and thus resulting in poorer quality coffee (DaMatta et al., 2007).

\footnotetext{
${ }^{1}$ Empresa de Pesquisa Agropecuária de Minas Gerais/EPAMIG - Lavras - MG - Brasil

${ }^{2}$ Universidade Federal de Lavras/UFLA - Cx. P. 3037 - CEP 37200-00 - Lavras - MG - Brasil - krdazio@hotmail.com

${ }^{3}$ Universidade Federal de Lavras/UFLA - Departamento de Biologia/DBI - Lavras - MG - Brasil

${ }^{4}$ Universidade Federal de Lavras/UFLA - Lavras - MG - Brasil

Received in july 2, 2014 and approved in december 3, 2014
}

Ciênc. Agrotec., Lavras, v.39, n.2, p.138-146, mar./abr., 2015 
Generally, waterlogging restricts the cultivation of plant species that are poorly adapted to low oxygen availability (Perata; Armstrong; Voesenek, 2011). Under this environmental condition, the photosynthetic rates of non-tolerant species (Chen; Qualls; Blank, 2005) are reduced by stomatal closure, chlorophyll degradation (Mauchamp; Méthy, 2004) and increased flow dissipation per reaction center (Martinazzo et al., 2013).

In addition to the direct effects on photosynthesis, plant metabolism and the partitioning of carbohydrates are highly affected by excess water in the soil (Chen et al., 2005; Ferner; Rennenberg; Kreuzwieser 2012; Zanandrea et al., 2010). Submerged plants can suffer from a loss of carbohydrate reserves and slower photosynthesis due to the lack of light and carbon dioxide (Boamfa et al., 2005). By contrast, the accumulation of soluble sugars in the roots of plants under soil flooding has been reported as a survival strategy in response to this stress (Zanandrea et al., 2010).

Although plant responses to water excess have often been considered, there are few studies related to the physiological alterations in coffee plants exposed to this condition. We therefore evaluated the effect of the waterlogging on gas exchange, the metabolism and partitioning of carbohydrates and the levels of photosynthetic pigments in seedlings of two commercial coffee cultivars (Mundo Novo and Catuaí).

\section{MATERIAL AND METHODS}

The experiment was conducted in a greenhouse at the Universidade Federal de Lavras. Coffee seedlings of Mundo Novo IAC 379-19 and Catuaí Vermelho IAC 44 cultivars containing four pairs of fully expanded leaves were transplanted to polyethylene bags $(15 \times 25 \mathrm{~cm}$ and 4.4 liters in volume) containing the standard substrate for coffee (Guimarães; Mendes; Souza, 2002).

After acclimation, seedlings with eight pairs of fully expanded leaves were subjected to three different conditions of substrate water availability. Control seedlings were maintained with substrate moisture close to field capacity (FC) and were irrigated daily. The second treatment was the intermittent waterlogging of the substrate (IW), in which, throughout the experimental period, the plants were alternately subjected to three days of continuous waterlogging and four days of water at field capacity. The third treatment was continuous waterlogging of the substrate $(\mathrm{CW})$, in which the seedlings were maintained under a permanent layer of water covering two-thirds of the height of the polyethylene bag. The humidity of the substrate was monitored according to Bernardo, Soares and Mantovani (2006).

Gas exchange was evaluated monthly (the first evaluation was performed before the imposition of the treatments, and the final evaluation was performed at the end of the experiment) in fully expanded leaves from the upper third of the seedlings. The biochemical analyses were performed at three different times: one week after the initiation of the treatments (February - Time 1); two months after the initiation of the treatments, when leaves were yellowing and seedling growth of the continuously waterlogged plants was visibly reduced (April - Time 2); and after five months, when defoliation and worsening of symptoms were observed in continuously waterlogged plants (June - Time 3). During each of the three harvesting times, the plants in the IW treatment were in the recovery phase (on the fourth day of water at field capacity). Roots and leaves were collected and stored for biochemical analyses in four biological replicates.

Chlorophyll and carotenoid levels were determined as described by Lichtenthaler and Buschmann (2001). For these assays, $100 \mathrm{mg}$ of leaves were ground in $80 \%$ acetone with a final volume of $10 \mathrm{ml}$. Then, the samples were read in a spectrophotometer at 645 and $663 \mathrm{~nm}$ for chlorophyll measurement and at $445 \mathrm{~nm}$ for carotenoid content.

Gas exchange was assessed using a portable infrared gas analyzer (IRGA - ADC-LCA4). The parameters evaluated were as follows: net photosynthetic rate $\left(\mathrm{A}_{\text {net }}\right)$, transpiration $(\mathrm{E})$, stomatal conductance $\left(\mathrm{g}_{\mathrm{s}}\right)$, intercellular $\mathrm{CO}_{2}$ concentration $\left(\mathrm{C}_{\mathrm{i}}\right)$, and atmospheric $\mathrm{CO}_{2}$ concentration $\left(\mathrm{C}_{\mathrm{a}}\right)$. The water use efficiency $\left(\mathrm{A}_{\text {net }} / \mathrm{E}\right)$ and the ratio between intercellular and atmospheric $\mathrm{CO}_{2}$ $(\mathrm{Ci} / \mathrm{Ca})$ were calculated. The evaluations were performed on days with low cloud cover between 0900 and $1000 \mathrm{~h}$ (solar time). Two leaves per plant were analyzed, with four biological replicates. It was used natural source of radiation and $\mathrm{CO}_{2}$ from the environment.

Reducing sugars were extracted from leaves and roots by homogenizing $200 \mathrm{mg}$ of dry matter in $5 \mathrm{ml}$ of $100 \mathrm{mM}$ potassium phosphate ( $\mathrm{pH}$ 7.0). Then, the samples were incubated in a water bath at $40{ }^{\circ} \mathrm{C}$ for 30 minutes, followed by centrifugation at $5000 \mathrm{~g}$ for 10 minutes (Zanandrea et al., 2010). The process was repeated, and the supernatants were combined and used for quantification. Finally, reducing sugars were quantified according to Miller (1959). For starch extraction, the pellet from the extraction described above was solubilized in $8 \mathrm{ml}$ of 200 $\mathrm{mM}$ potassium acetate ( $\mathrm{pH} 4.8$ ), followed by the addition of 16 units of amyloglucosidase to each sample. After incubation in a water bath for $120 \mathrm{~min}$, samples were 
centrifuged at $5000 \mathrm{~g}$ for 20 minutes, and the volume of the supernatant was increased to $15 \mathrm{ml}$. Starch was quantified as described by Dische (1962).

The experimental design was randomized blocks, with four biological replicates, three different soil water availability treatments (FC, IW and CW) and two cultivars (Mundo Novo and Catuaí). Each experimental plot consisted of eight plants, totaling 96 plants per cultivar. The data were subjected to analysis of variance, and the means of the treatments were compared using the Scott-Knott test at 0.05 probability or were subjected to regression analysis using the statistical program SISVAR 4.3.

\section{RESULTS AND DISCUSSION}

Catuaí seedlings did not show changes in photosynthetic pigments due to waterlogging (Figure 1). In contrast, waterlogged Mundo Novo seedlings were characterized by a lower content of carotenoids by the second evaluation. Chlorophyll content increased at the second evaluation and decreased by the final evaluation for all treatments and varieties, with the exception of Mundo Novo under continuous waterlogging. The pattern for carotenoid content was more complex: the Catuaí variety had a lower initial level than the Mundo Novo variety, but the Catuaí variety showed decreases in all treatments at the second evaluation and then returned to the pre-evaluation levels. The Mundo Novo variety showed a similar but more marked trend, decreasing sharply by the second evaluation and remaining at a lower level in the final evaluation.

Despite the small variations in the contents of photosynthetic pigments, waterlogging reduced the photosynthetic rates of both cultivars proportionally to the intensity and the time of the exposure to stress (Figure 2). Under the FC treatment, photosynthetic rates decreased in Catuaí cultivar seedlings and remained approximately constant in Mundo Novo seedlings throughout the experimental period. $A_{\text {net }}$ decreased throughout the experiment in Mundo Novo and Catuaí cultivars submitted to intermittent waterlogging, showing quadratic and linear trends, respectively. Quadratic declines were observed for both cultivars under $\mathrm{CW}$, with photosynthetic rates dropping to near zero at the end of the experimental period.

Transpiration was affected by the time and the intensity of the hypoxic stress to which seedlings were submitted (Figure 3). In Catuaí seedlings, transpiration decreased linearly for all of the treatments, whereas in Mundo Novo seedlings, the trend was quadratic. At the fifth month, seedlings from all treatments showed similar transpiration rates.

For the FC and IW treatments, water use efficiency remained constant until the third month of evaluation and then increased during the two last months (Figure 4).
A

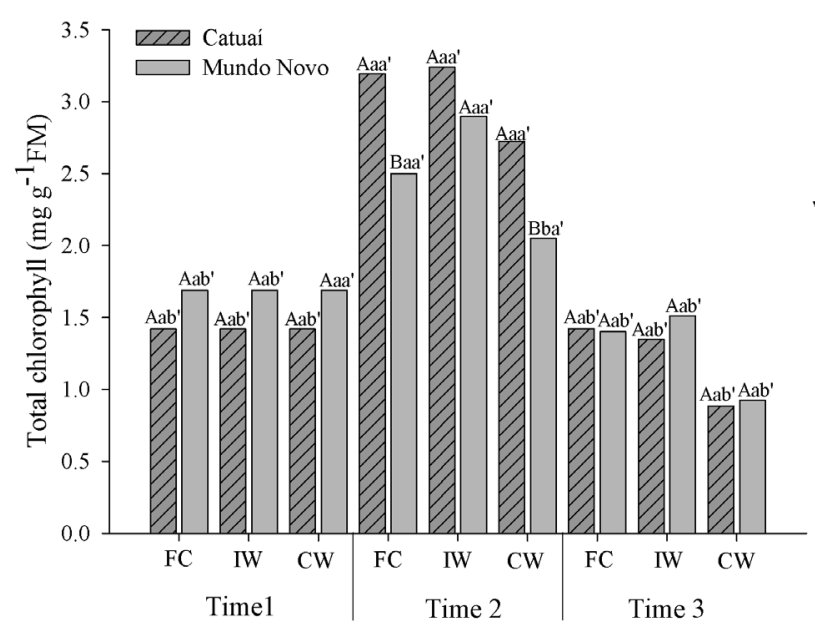

$\mathrm{B}$

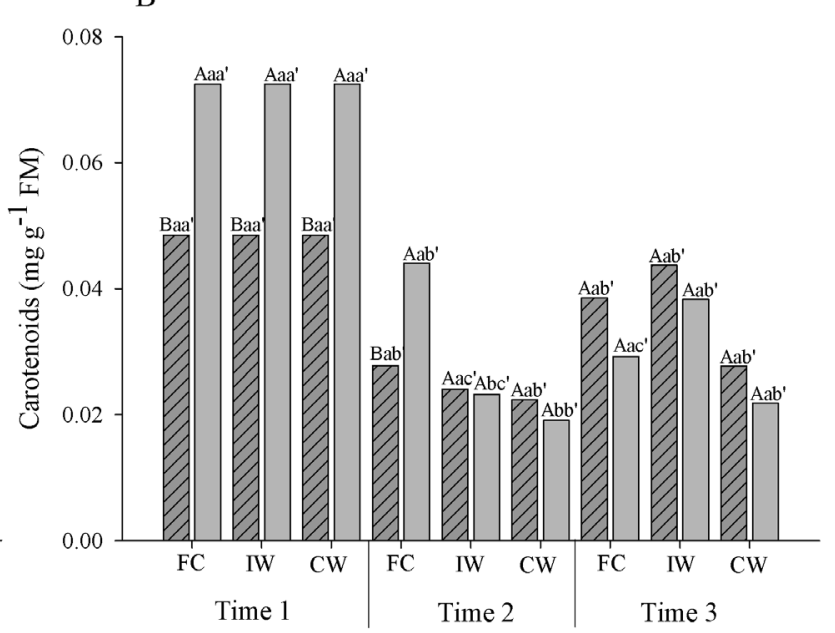

Figure 1: Total chlorophyll (A) and carotenoid (B) levels in Catuaí and Mundo Novo cultivars submitted to FC (field capacity); IW (intermittent waterlogging); CW (continuous waterlogging). Capital letters indicate comparisons between cultivars in each evaluation time, within each treatment; lowercase letters indicate comparisons among the treatments within each cultivar in each time; and lowercase letters followed by apostrophes indicate comparisons of each cultivar within each treatment, over the evaluation time, based on the Scott-Knott test $(p \leq 0.05)$. 
A

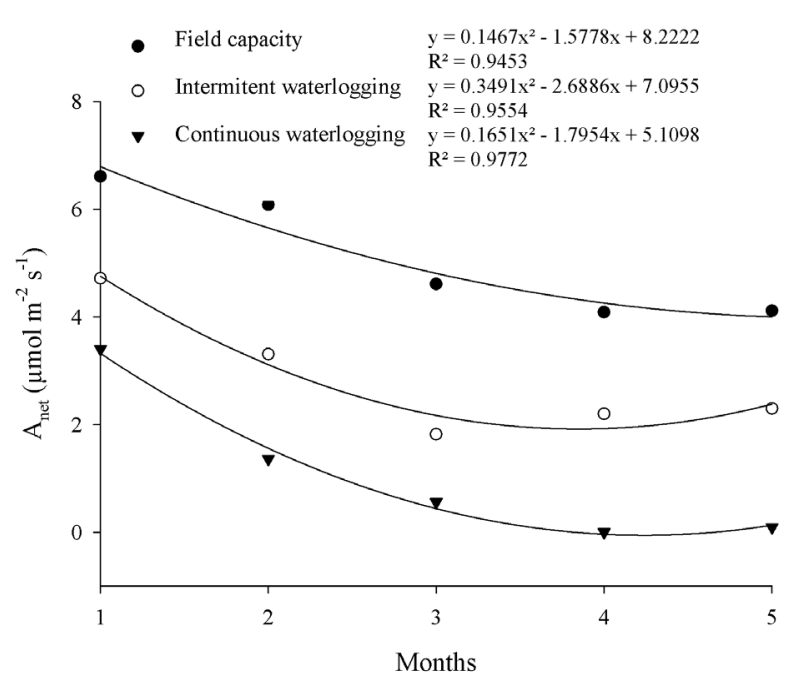

B

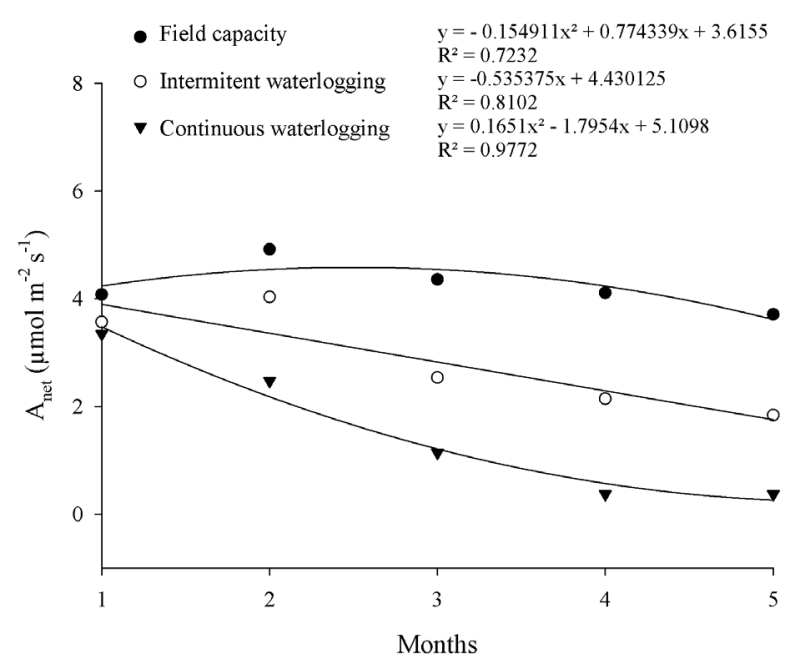

Figure 2: Net photosynthesis rate $\left(\mathrm{A}_{\text {net }}\right)$ of coffee seedlings of Catuaí $(\mathrm{A})$ and Mundo Novo (B) varieties submitted to FC (field capacity); IW (intermittent waterlogging) or CW (continuous waterlogging) for five months.
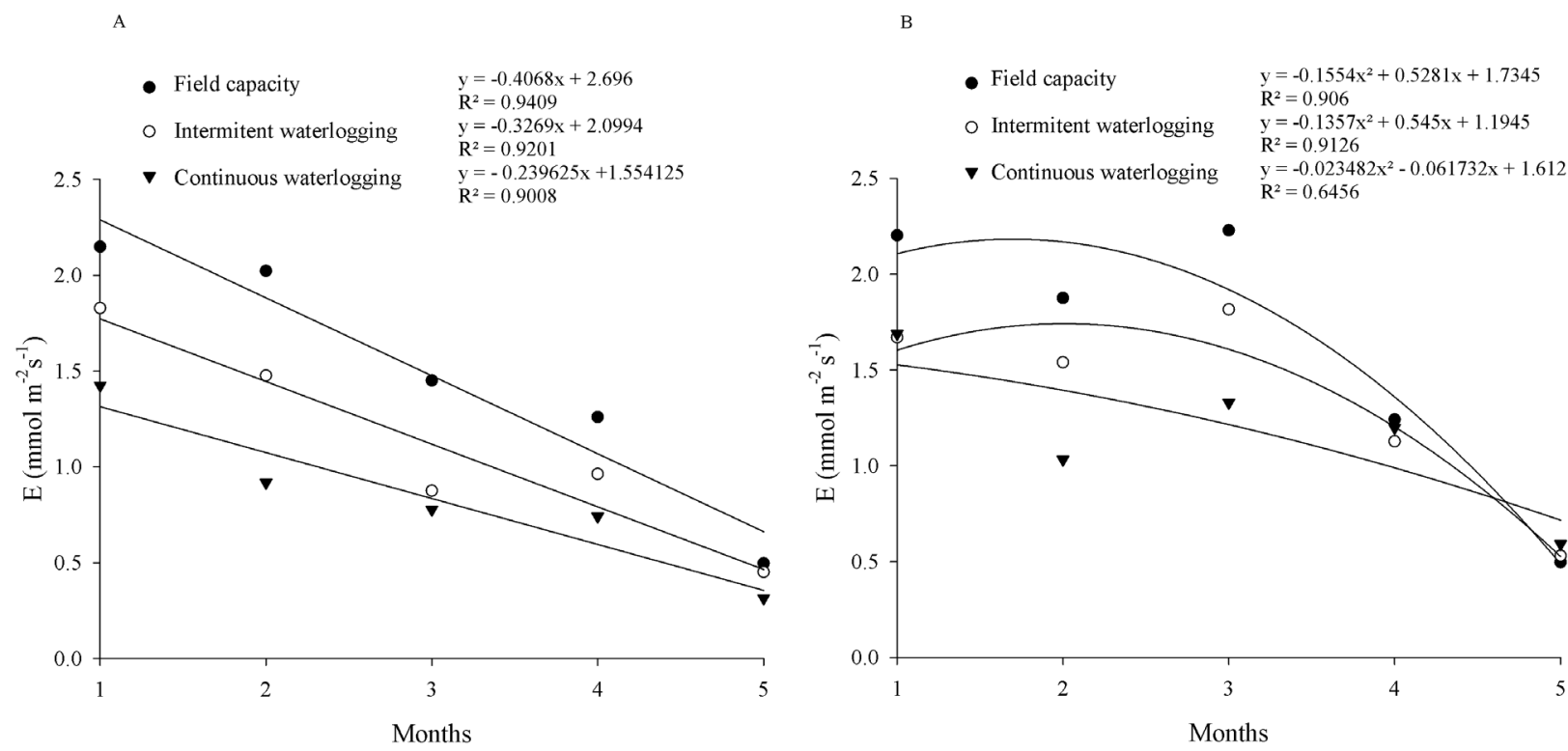

Figure 3: Transpiration (E) of coffee Catuaí (A) and Mundo Novo (B) seedlings submitted to FC (field capacity); IW (intermittent waterlogging) or $\mathrm{CW}$ (continuous waterlogging) over the five months of the experiment.

This increase was due to the decreases in temperature and stomatal conductance, decreasing the transpiration rates. There was a more pronounced decrease in transpiration than in photosynthetic rates, thus leading to an increase in WUE of plants in the FC and IW groups. In plants under $\mathrm{CW}$, the minimal values of photosynthetic rates together with the reduction in transpiration rates led to a reduced WUE.

Independent of treatment or cultivar, there was a decrease in stomatal conductance with the continuation of the stress (Figure $5 \mathrm{~A}$ ). At the end of the experiment, all of the plants had the same levels of stomatal closure. 
In addition to $\mathrm{A}_{\text {net }}$, $\mathrm{E}$ and $\mathrm{g}_{\mathrm{s}}$, the $\mathrm{Ci} / \mathrm{Ca}$ ratio was affected by the waterlogging. This ratio increased in seedlings of both cultivars submitted to continuous waterlogging (Figure 5 B).
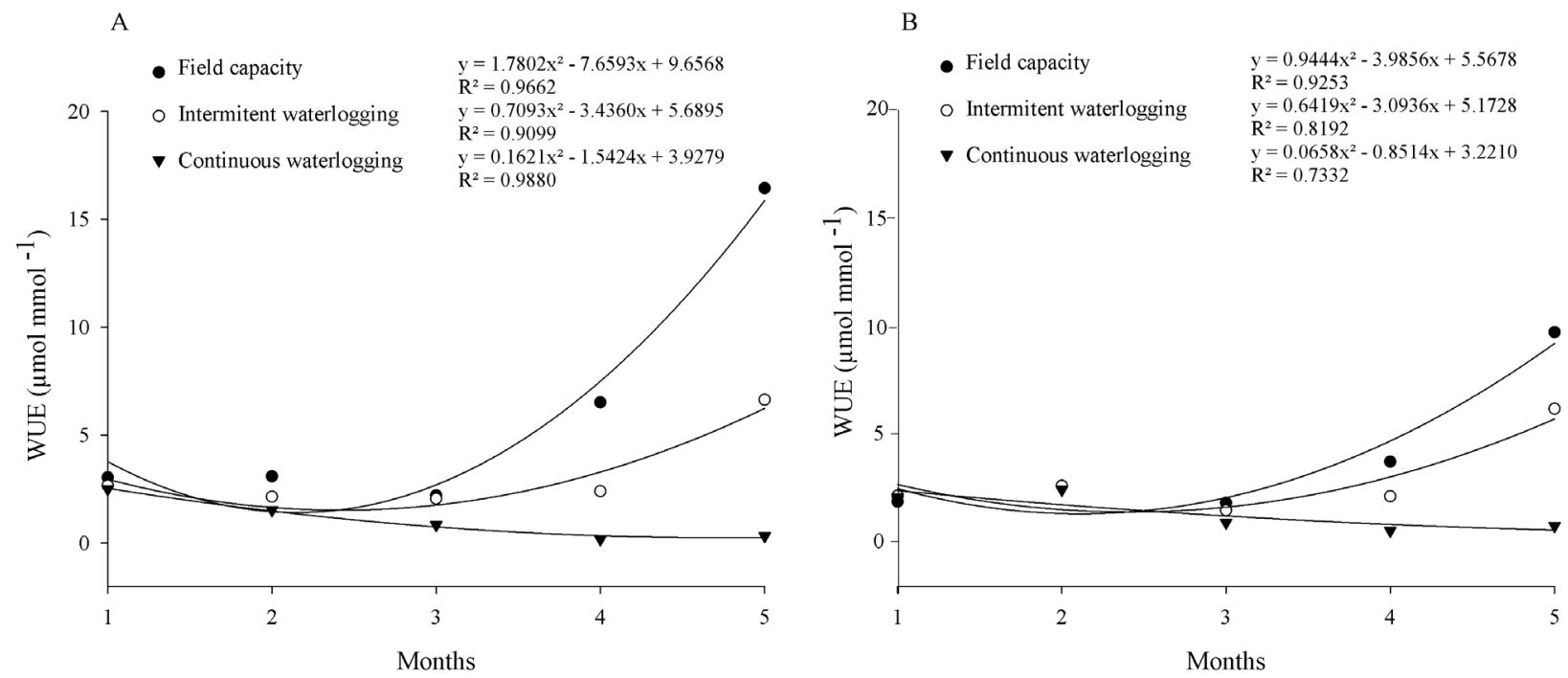

Figure 4: WUE (Water use efficiency) of coffee Catuaí (A) and Mundo Novo (B) submitted to FC (field capacity); IW (intermittent waterlogging) and $\mathrm{CW}$ (continuous waterlogging) over the five months of the experiment.

A

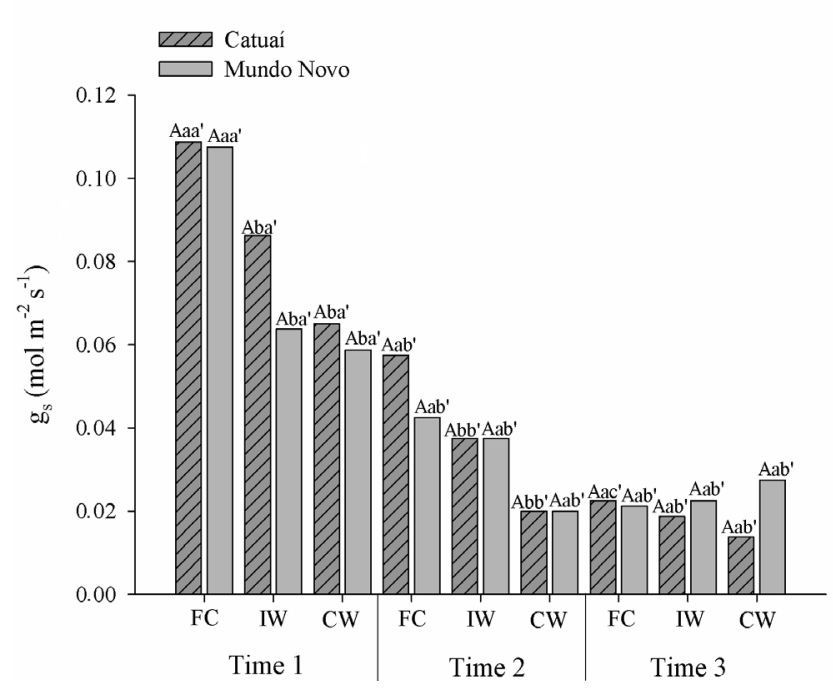

B

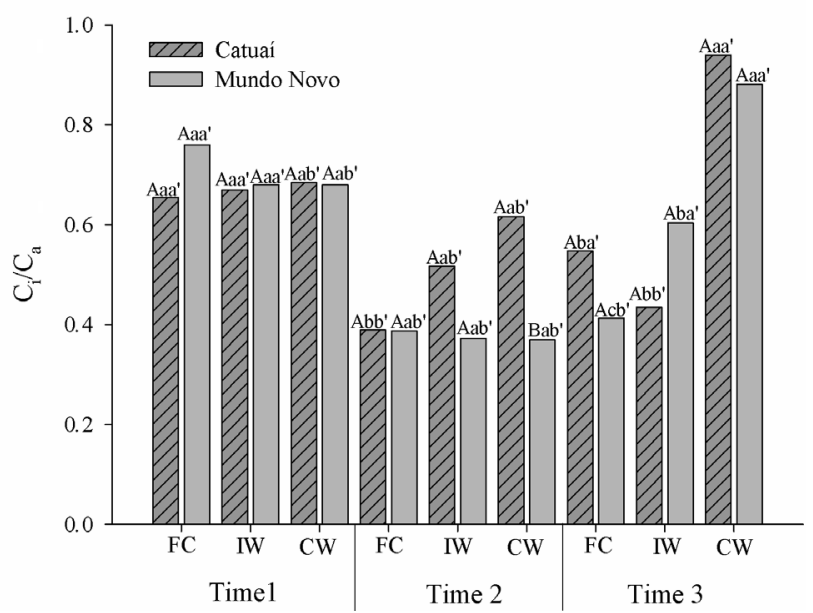

Figure 5: Stomatal conductance $-\mathrm{g}_{\mathrm{s}}(\mathrm{A})$ and the ratio between intercellular and atmospheric $\mathrm{CO}_{2}-\mathrm{Ci} / \mathrm{Ca}(\mathrm{B})$ of Catuaí and Mundo Novo cultivars submitted to FC (f ield capacity); IW (intermittent waterlogging) or CW (continuous waterlogging). Capital letters indicate comparisons between cultivars at each evaluation time, within each treatment; lowercase letters indicate comparisons among the treatments within each cultivar at each time; and lowercase letters followed by apostrophes indicate comparisons of each cultivar within each treatment, over the evaluation time, based on the Scott-Knott test $(p \leq 0.05)$. 
Along with its effects on gas exchange, waterlogging affected carbohydrate metabolism in coffee seedlings. The concentrations of reducing sugars (Figure $6 \mathrm{~A}$ ) and starch (Figure $6 \mathrm{C}$ ) in leaves generally increased through the experiment, whereas net photosynthetic rates decreased (Figure 2). In roots (Figure $6 \mathrm{~B}$ and $\mathrm{D}$ ), the sugar concentrations remained constant or, as in both cultivars under $\mathrm{CW}$, were reduced by the end of the experiment. By the second evaluation, when temperatures were mild and the only source of stress was soil waterlogging, the concentration of reducing sugars in Catuaí seedlings increased with the waterlogging, but it remained constant for Mundo Novo seedlings. At this same sampling time, the net photosynthetic rates of plants under waterlogging showed a smaller decrease than in the final two months of the experiment. Coffee plants submitted to waterlogging accumulate reducing sugars more quickly in leaves than roots. This finding helps explain the results of Silveira et al. (2014), in which there was higher shoot growth than root growth in coffee plants submitted to the same condition of hypoxic stress.
A

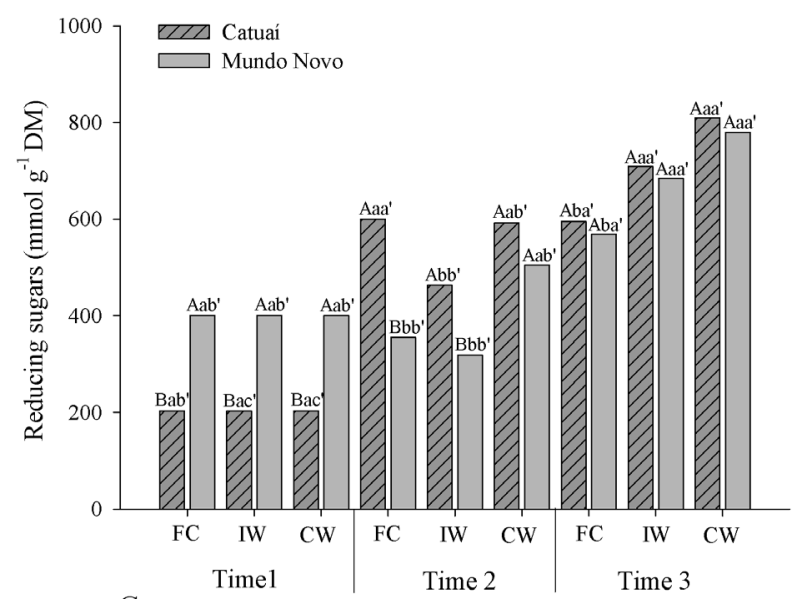

C

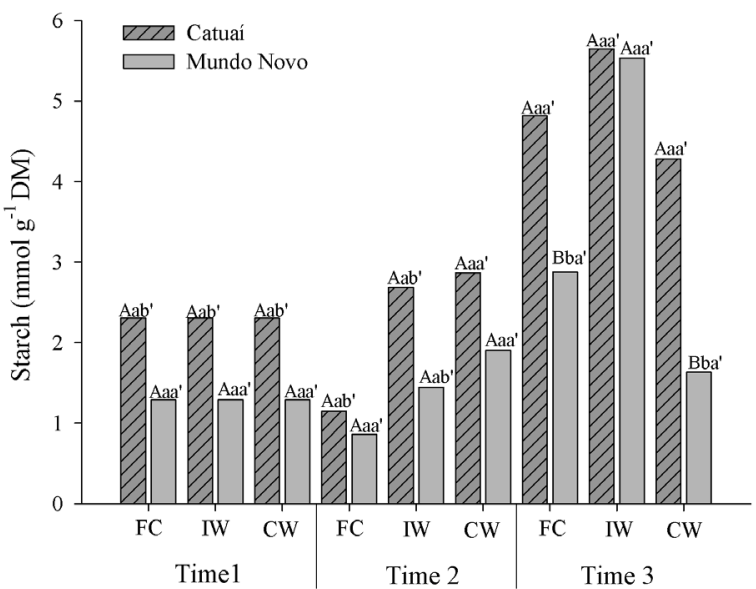

B

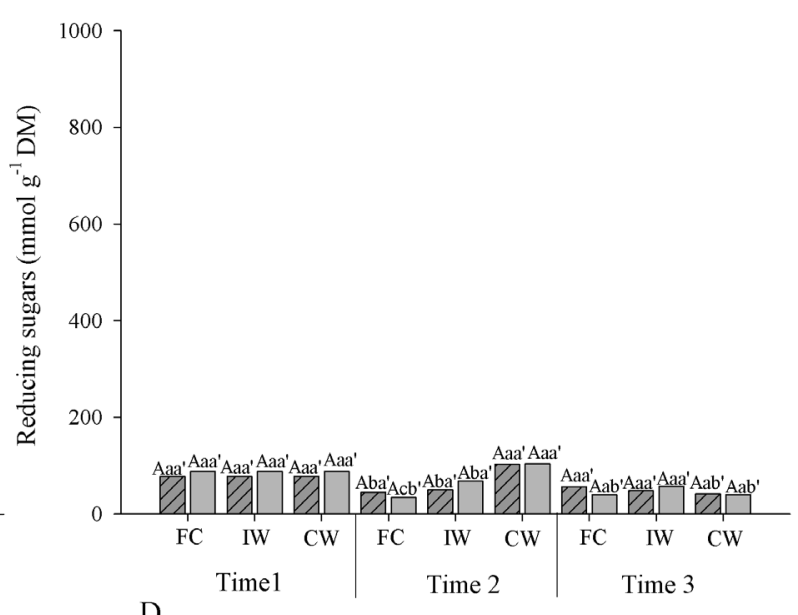

D

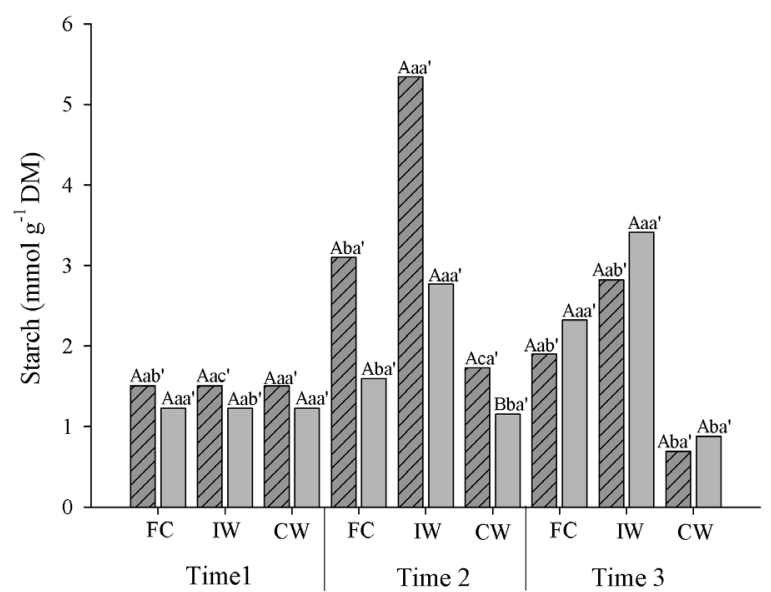

Figure 6: Levels of reducing sugars and starch in leaves (A, C) and roots (B, D) of Catuaí and Mundo Novo seedlings submitted to FC (field capacity); IW (intermittent waterlogging) or CW (continuous waterlogging). Capital letters indicate comparisons between cultivars in each evaluation time, within each treatment; lowercase letters indicate comparisons among the treatments within each cultivar in each time; and lowercase letters followed by apostrophes indicate comparisons of each cultivar within each treatment, over the evaluation time, based on the Scott-Knott test $(\mathrm{p} \leq 0.05)$. 
In general, plants submitted to waterlogging show a range of responses to the oxygen deficiency in the soil, such as yellowing of leaves and reductions in the photosynthetic rate and stomatal conductance (Bertoldi et al., 2012; Ferner; Rennenberg; Kreuzwieser, 2012). In this study, the variation in gas exchange likely reflected stomatal behavior during the experiment because there were decreases in photosynthetic (Figure 2) and transpiration (Figure 3) rates and in stomatal conductance (Figure $5 \mathrm{~A}$ ) for all treatments (CW, IW, FC) during the experiment. The decreases in these parameters under FC indicate that other factors, not related to waterlogging, negatively influenced the metabolism of the seedlings. As described above, the experiment was conducted from summer until autumn in a greenhouse. Thus, there were seasonal changes in temperature and radiation, and the meteorological variables were not controlled. There were variations in vapor pressure deficit (VPD), although the atmospheric $\mathrm{CO}_{2}$ concentration was constant through the experimental time. Further, the variations in temperature and photosynthetically active radiation (PAR) were similar, decreasing during the last two months of evaluation, characteristic of autumn (Figure 7).

Seasonal variations in photosynthetic rates and stomatal conductance in tree species of tropical regions are related to typical VPD, temperature, solar radiation and soil humidity during each season. Thus, variations in gas exchange may be simultaneously affected by climatic and physiological variations (Machado et al., 2002).

In coffee, gas exchange parameters can vary based on minimum temperatures: below $15{ }^{\circ} \mathrm{C}$, physiological processes such as photosynthesis are inhibited (Amaral; Rena; Amaral, 2006). The rate of decrease of photosynthesis was higher in the first three months of waterlogging than in the final two months, particularly in the Catuai cultivar (Figure 2). After the lowest temperatures were detected, during the final two months, the decrease in the photosynthetic rates can be primarily attributed to the waterlogging. This suggests that Catuaí seedlings suffered negative effects of hypoxic stress earlier than did the Mundo Novo seedlings. The decrease in photosynthesis was likely related to the lower growth rates of the seedlings under intermittent and continuous waterlogging (Silveira et al., 2014).

Despite the seasonal influence of the climate, our data suggest that waterlogging influenced the $A_{\text {net }}$ rates of both cultivars by the end of the experiment. Flooding decreases net photosynthesis of woody plant species (Dalmolin et al., 2013), mainly due to stomatal closure, which results in lower $\mathrm{CO}_{2}$ absorption by leaves. Stomatal closure also causes decreases in the carboxylation efficiency, photon-saturated photosynthetic rate, and apparent quantum yield of $\mathrm{CO}_{2}$ fixation (Fernández, 2006). Considering that the atmospheric $\mathrm{CO}_{2}$ concentration was constant (Figure 7A), the increase in the $\mathrm{C}_{\mathrm{i}} / \mathrm{C}_{\mathrm{a}}$ ratio (Figure $5 \mathrm{~B}$ ) was caused only by variations in the intercellular concentrations of carbon. Stomatal conductance and transpiration were similar in control and waterlogged seedlings at five months. The decrease in net photosynthesis may therefore be directly related to the decrease in the metabolic activity of carboxylation reactions. In addition to the inhibition of Calvin Cycle enzymes, degradation of photosynthetic pigments can contribute to low carboxylation efficiency or quantic efficiency (Konrad et al., 2005; Silva et al., 2012). Thus,
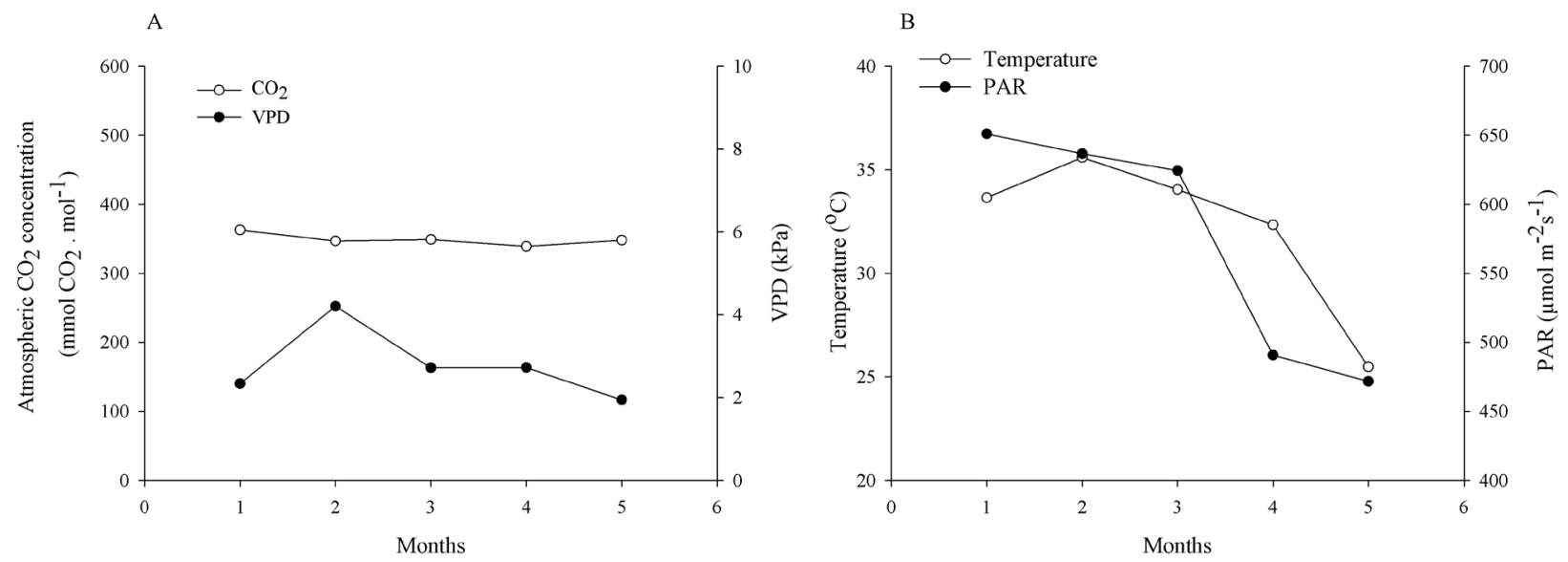

Figure 7: Atmospheric $\mathrm{CO}_{2}$ concentration, VPD (vapor pressure deficit), temperature and photosynthetically active radiation (PAR) during the experimental period. 
there may have been a biochemical limitation on photosynthesis. In coffee plants, net photosynthetic rates can be influenced by stomatal limitations in summer (Silva et al., 2004) and by biochemical resistances in the chloroplasts in autumn (Amaral et al., 2006).

The concentrations of soluble sugars and carbohydrates in leaves represent a balance between what is produced by photosynthesis and what is used for growth and metabolic expenses or exported to sink organs (Alves et al., 2011). Coffee plants showed severe reductions in net photosynthetic rate when submitted to waterlogging. Meanwhile, carbohydrates accumulated in leaves due to lower rates of sugar translocation through the phloem, and there was a consequently lower carbohydrate supply to the roots. Thus, the death of absorbent roots and the inhibition of plant development (Silveira et al., 2014) of coffee seedlings under soil waterlogging may originate from the reduced translocation of sugars from the leaves to the roots (Bertolde et al., 2012; Kreuzwieser; Papadopoulou; Rennenberg, 2004).

When translocated to the roots, carbohydrates are consumed in the glycolytic pathway, providing energy under low oxygen concentrations. The high availability of respiratory substrates can be a determining factor for the survival of root tissues in hypoxic environments (Ferner; Rennenberg; Kreuzwieser, 2012; Fukao; Bailey-Serres, 2004). In the metabolism of plants under low oxygen availability, cells begin anaerobic fermentation, in which they generate two ATPs per catabolized glucose molecule. Nevertheless, the anaerobic pathway requires large amounts of sugars in the root tissues to generate enough ATP to maintain the cell metabolic activities under hypoxia (Fukao; Bailey-Serres, 2004). In our study, we detected a drastic reduction in carbohydrate supply for roots in plants under waterlogging. Both Catuaí and Mundo Novo cultivars showed reduced carbohydrate translocation to the roots after only three months of stress.

\section{CONCLUSIONS}

Although many physiological parameters were affected by waterlogging, the cultivars used in our study survived for five months under stressful conditions. Obviously, it was not expected that tolerant plants under stress would exhibit the same intensity of physiological and biochemical processes as plants under normal conditions. Still, under either continuous or intermittent waterlogging, Catuaí and Mundo Novo seedlings were able to tolerate up to at least three months of waterlogging stress.

\section{ACKNOWLEDGMENTS}

We thank the Fundação de Amparo à Pesquisa do Estado de Minas Gerais (FAPEMIG) and the Conselho Nacional de Desenvolvimento Científico e Tecnológico (CNPq) for the granting of scholarships and the CNPq for its financial support in conducting this research.

\section{REFERENCES}

ALVES, J. D. et al. Source-sink manipulations in Coffea arabica $\mathrm{L}$. and its effect on growth of shoots and root system. Ciência e Agrotecnologia. 35(5):956-964, 2011.

AMARAL, J. A. T.; RENA, A. B.; AMARAL, J. F. T. Crescimento vegetativo sazonal do cafeeiro e sua relação com fotoperíodo, frutificação, resistência estomática e fotossíntese. Pesquisa Agropecuária Brasileira. 41(3):377-384, 2006.

BERNARDO, S.; SOARES, A. A.; MANTOVANI, E. C. Manual de Irrigação. 8. ed. Viçosa: UFV, 2006. 625 p.

BERTOLDI, F. Z. et al. Physiological and biochemical responses of Theobroma cacao L. genotypes to flooding. Photosynthetica. 50(3):447-457, 2012.

BOAMFA, E. I. et al. Kinetics of ethanol and acetaldehyde release suggest a role for acetaldehyde production in tolerance of rice seedlings to micro-aerobic conditions. Annals of Botany. 96(4):727-736, 2005.

CHEN, H.; QUALLS, R. G.; BLANK, R. R. Effect of soil flooding on photosynthesis, carbohydrate partitioning and nutrient uptake in the invasive exotic Lepidium latifolium. Aquatic Botany. 82(4):250-268, 2005.

DALMOLIN, A. C. et al. Photosynthetic light and carbon dioxide response of the invasive tree, Vochysia divergens Pohl, to experimental flooding and shading. Photosynthetica. 51(3):379-386, 2013.

DAMATTA, F. M. et al. Ecophysiology of coffee growth and production. Brazilian Journal of Plant Physiology. 19(4):485-510, 2007.

DISCHE, Z. General color reactions. In: WHISTLER, R. L.; WOLFRAM, M. L. Methods of carbohydrate chemistry. London: Academic Press, 1962. p. 484-488. 
FERNÁNDEZ, M. D. Changes in photosynthesis and fluorescence in response to flooding in emerged and submerged leaves of Pouteria orinocoensis.

Photosynthetica. 44(1):32-38, 2006.

FERNER, E.; RENNENBERG, H.; KREUZWIESER, $\mathrm{J}$. Effect of flooding on C metabolism of floodtolerant (Quercus robur) and non-tolerant (Fagus sylvatica) tree species. Tree Physiology. 32(2):135145, 2012.

FUKAO, T.; BAILEY-SERRES, J. Plant responses to hypoxia - is survival a balancing act? Trends in Plant Science. 9(9):449- 456, 2004.

GUIMARÃES, R. J.; MENDES, A. N. G.; SOUZA, C. A. S. Cafeicultura. Lavras: UFLA/FAEPE, 2002. $317 \mathrm{p}$.

KONRAD, M. L. F. et al. Trocas gasosas e fluorescência da clorofila em seis cultivares de cafeeiro sob estresse de alumínio. Bragantia. 64(3):339-347, 2005.

KREUZWIESER, J.; PAPADOPOULOU, E.; RENNENBERG, $\mathrm{H}$. Interaction of flooding with carbon metabolism of forest trees. Plant Biology. 6(3):299-306, 2004.

LEMOS FILHO, L. C. A. et al. Spatial-temporal analysis of water requirements of coffee crop in Minas Gerais State, Brazil. Revista Brasileira de Engenharia Agrícola e Ambiental. 14(2):165-172, 2010.

LICHTENTHALER, H. K.; BUSCHMANN, C. Chorophylls and carotenoids: measurement and characterization by UV-VIS spectroscopy. In: WROLSTAD, R. E. et al. Current Protocols in Food Analytical Chemistry. Davis: John Wiley \& Sons, 2001. p. F4.3.1-F 4.3.8.

MACHADO, E. C. et al. Variação sazonal de fotossíntese, condutância estomática e potencial da água na folha de laranjeira "Valência". Scientia Agricola. 59(1):53-58, 2002.

MARTINAZZO, E. G. et al. Atividade fotossintética em plantas de ameixeira submetidas ao déficit hídrico e ao alagamento. Ciência Rural. 43(1), 35-41, 2013.

MAUCHAMP A.; MÉTHY M. Submergence-induced damage of photosynthetic apparatus in Phragmites australis. Environmental and Experimental Botany. 51(3):227-235, 2004.

MILLER, G. L. Use of dinitrosalicylic acid reagent for determination of reducing sugar. Analytical Chemistry. 31(3):426-428, 1959.

PERATA, P.; ARMSTRONG, W.; VOESENEK, L. A. C. J. Plants and flooding stress. New Phytologist. 190(2):269-273, 2011.

ROTONDANO, A. K. F. et al. Desenvolvimento vegetativo, produção e qualidade dos grãos do cafeeiro (Coffea arabica L.) sob diferentes lâminas de irrigação.

Bioscience Journal. 21(1):65-75, 2005.

SILVA, E. A. et al. Seasonal changes in vegetative growth and photosynthesis of Arabica coffee trees. Field Crops Research. 89(2):349-357, 2004.

SILVA, E. N. et al. Coordinate changes in photosynthesis, sugar accumulation and antioxidative enzymes improve the performance of Jatropha curcas plants under drought stress. Biomass and bioenergy. 45(1):270-279, 2012.

SILVEIRA, H. R. O. et al. Growth effects of water excess on coffee seedlings (Coffea arabica L.). Acta Scientiarum. Agronomy. 36(2):211-218, 2014.

ZANANDREA, I. et al. Tolerance of Sesbania virgata plants to flooding. Australian Journal of Botany. 57(8):661-669, 2010. 